\title{
O uso do Imposto sobre a Propriedade Territorial Urbana como mecanismo de tutela do Patrimônio Histórico e Arquitetônico das Cidades
}

\author{
Use of Urban Property Tax as a protective mechanism of Historical and Architectural \\ Patrimony of the Cities
}

\author{
Marcelle Mourelle Perez Diós ${ }^{1}$
}

\begin{abstract}
RESUMO
O presente trabalho tem a finalidade de tecer considerações acerca do caráter extrafiscal do Imposto sobre a Propriedade Predial e Territorial Urbana - IPTU, em relação à proteção ao patrimônio histórico e arquitetônico das cidades, através da abordagem vinculativa entre a extrafiscalidade tributária como meio de efetivação da função social da propriedade. Para tanto, serão considerados os mecanismos administrativos de limitação à propriedade privada, bem como a forma estatal de cobrança dos tributos reais, a fim de reiterar o liame existente entre o referido tributo e sua importância na proteção do patrimônio histórico e arquitetônico.
\end{abstract}

Palavras-chave: Imposto sobre a Propriedade Predial e Territorial Urbana; IPTU; Extrafiscalidade, Função Social da Propriedade; Patrimônio Histórico e Arquitetônico.

\begin{abstract}
This paper aims to develop some considerations about the nature of Urban Property Tax in relation to protecting the historical and architectural patrimony of the cities, by binding approach between the stimulating tax as a means of effecting the principle of social function of property. For this, we considered the administrative limitation of private property and the state form of actual tax collection in order to renew the bond that exists between that tax and its importance in protecting the historical and architectural patrimony.
\end{abstract}

Keywords: Urban Property Tax, Social Function of Property, Historical and Architectural Patrimony.

\section{CONSIDERAÇÕES INICIAIS}

Todas as cidades são centros de convivência. Elas representam pólos de concentração de diversos grupos sociais que necessitam interagir e respeitar-se para que a comunidade urbana seja possível. Nelas, existem uma série de elementos físicos, como ruas, prédios, mercados e indústrias, que servem de instrumentos para que as pessoas tenham o modo de vida urbano. Atualmente, as cidades e a vida urbana são consideradas naturais para a grande maioria da população, inclusive a brasileira. Todavia, as cidades são fruto da evolução de um fenômeno social e cultural ${ }^{2}$.

\footnotetext{
${ }^{1}$ Mestranda da UERJ.

${ }^{2}$ Neste contexto vale destacar a reflexão da arquiteta e professora Ana Paula Medeiros: “A cidade é, assim, o lugar que resultou desse salto, o habitat do homo urbes. A cidade - e tudo o que ela significa, em cada uma de suas faces - é o lugar, por excelência, onde se manifestam e resolvem os conflitos, se criam e dissolvem as
} 
Portanto, isto não significa que não existam comunidades rurais ou interação de grupos sociais diversos no campo, mas que as relações urbanas e rurais possuem dinâmicas distintas.

Tais premissas também não querem dizer que as cidades funcionem perfeitamente. A convivência urbana com acesso as necessidades básicas - como água, alimentação, a saúde, educação e saneamento - e em uma atmosfera de tolerância e respeito à diversidade.

Infelizmente, ainda não foi plenamente concretizada nem nos países com melhores índices de desenvolvimento humano (IDH) ou com maiores produtos internos brutos (PIB). Isto por que elas são fruto do referido fenômeno em constante aperfeiçoamento por ser resultado da ação humana.

No Brasil, pode parecer uma utopia pensar que as cidades podem vir a ser algo próximo deste paradigma, tendo em vista o mar de problemas encontrados em nossos centros urbanos. A desigualdade social, a violência, o preconceito, o desemprego, a especulação imobiliária, a degradação contínua do meio ambiente e as falhas dos sistemas de saúde e educação são alguns dos muitos desafios para todos os entes federados e para a sociedade civil.

O Estado, como se pode ver, não deve ser o único responsável pela solução destas questões por dois motivos. São tantos os problemas que esperar uma solução totalmente pública representa, na prática, a multiplicação de todos eles em função da morosidade que as políticas públicas têm apresentado. Além disso, o nosso ordenamento prevê que o Estado não deve interferir profundamente na liberdade de agir e na propriedade dos cidadãos, mas, por outro lado, a sociedade civil deve atuar ativamente, respeitando a função social da propriedade, o meio ambiente e o patrimônio histórico e cultural.

Neste sentido, aperfeiçoam-se ao longo das últimas décadas os mecanismos de atuação paraestatal, ou seja, aqueles em que terceiros exercem a função pública, com o crescimento do Terceiro Setor e também os mecanismos de fomento à atuação de particulares na direção do interesse público de modo que o Estado seja auxiliado para o atendimento destas metas, formando um esforço coletivo em prol da eficiência em busca do interesse público.

tensões, onde se encontra e se desencontra todo tipo de gente, de jeito e de atuação. É o lugar da diferença, e, por conseguinte, da negociação constante, muda ou deflagrada, cordial ou belicosa.

O bárbaro ainda está aí, à espreita, e quanto mais esgarçados os laços que nos fizeram urbanos, que nos fizeram cidade; quanto mais fragmentados nossos vínculos de urbanidade e solidariedade, mais frágeis nos tornamos, mais vulneráveis ao retorno à selva, à violência. Por baixo da pele de cidadãos, ainda habita um homem cheio de potência e contradição." In MEDEIROS, Ana Paula. $\mathbf{E}$ para você o que é uma cidade? http://www.urbanamente.net/blog/2009/04/01/e-pra-voce-o-que-e-uma-cidade, consulta em 16/11/2009. 
Um instrumento tradicional de tutela do patrimônio histórico e cultural é o tombamento. Telles ${ }^{3}$ realiza apropriada definição do instituto e do ato de tombar:

Tombar é, portanto, consignar nestes livros [de registro] que determinada propriedade, seja pública ou privada, móvel ou imóvel, foi considerada de interesse sócia, submetida a partir daí, a um regime peculiar que objetiva protegê-la contra a destruição, abandono ou utilização inadequada.

Tombamento equivale, igualmente, a colocar sob o abrigo e a tutela pública os bens que, pelas características históricas, artísticas, naturais ou arqueológicas, mereçam integrar o patrimônio cultural do país.

O tombamento é um meio do Poder Público proteger um bem sem ter que retirá-lo do patrimônio de outrem. Deste modo, ele surge como um meio eficaz para que o Estado atue de modo eficiente ${ }^{4}$. Porém, apesar de invadir em menor escala os direitos dos proprietários, o tombamento gera reflexos na esfera jurídica destes cidadãos. Logo, o estudo das aplicações deste instituto é importante para a ampliação do seu uso de modo a aumentar a real eficácia do tombamento e evitar abusos que, na prática, impliquem em um ônus insuportável para o proprietário de um bem tombado.

Considerando este panorama, o presente trabalho busca contribuir para a formação de instrumentos de tutela do patrimônio histórico e cultural, oferecendo um mecanismo de tributação diferenciada para os bens imóveis tombados de modo a fomentar a sua conservação. Isto, pois há uma carência de trabalhos nesta seara e, em contrapartida, há uma imensa demanda de bens a serem protegidos e que estão sofrendo os árduos efeitos do tempo e do abandono.

Mundialmente, cresce o debate sobre a tutela do meio ambiente. Isto é fundamental para que se possa regulamentar o tema, pois - diferentemente do que acontece com outros temas - há interesse difuso ${ }^{5}$. Onde há este tipo de interesse, é imprescindível a especial

3 TELLES, Antônio A. Queiroz. Tombamento e seu regime jurídico. São Paulo: Editora Revista dos Tribunais, 1992. p.13.

4 Ensina, assim, MACHADO:

"Há diversas formas de proteção do patrimônio histórico-cultural, entre as quais estacamos o tombamento.

É importante que o Município disponha de uma legislação própria em matéria de proteção cultural, inclusive de tombamento. Dessa forma, se houver desídia da União ou dos Estados, ou houver diferença de entendimento entre as formas e métodos de conservação do referido patrimônio, o referido Município poderá implementar a sua própria legislação de proteção."

In MACHADO, Paulo Afonso Leme. Direito Ambiental Brasileiro. São Paulo: Malheiros Editores, 2005. p.391.

5 Nunes realiza didática diferenciação entre os interesses difusos, coletivos e individuais homogêneos: "Os chamados "direitos difusos" são aqueles cujos titulares não são determináveis. Isto é, os detentores do direito subjetivo que se pretende regrar e proteger são indeterminados e indetermináveis.

Isso não quer dizer que alguma pessoa em particular não esteja sofrendo a ameaça ou o dano concretamente falando, mas apenas e tão-somente que se trata de uma espécie de direito que, apesar de atingir alguém em particular, merece especial guarida porque atinge simultaneamente a todos. (...)

Nos chamados "direitos coletivos", os titulares do direito são também indeterminados, mas determináveis. Isto é, para a verificação da existência de um direito coletivo não há a necessidade de se apontar concretamente um 
atenção dos entes estatais, posto que nem sempre haverá uma postulação concreta em favor do interesse difuso pelo fato deste interesse estar disperso pela coletividade e não concentrado como, em regra, acontece com nos interesses de pessoas determinadas ou determináveis.

Vale destacar aqui que o patrimônio histórico e cultural faz parte do meio ambiente, pois é o reflexo da ação do homem sobre a natureza e, portanto, também deve ser incluído nas políticas públicas desta área. ${ }^{6}$

Mas por qual razão o patrimônio histórico e cultural é um interesse difuso?

O patrimônio histórico e cultural é formado por uma série de bens materiais e imateriais que registram os hábitos, o modo de vida e a cultura dos homens ao longo do tempo. A preservação destes elementos é fundamental para a o desenvolvimento futuro da sociedade, pois só assim é possível o estudo da evolução dos hábitos e das idéias dos homens para fins educativos e de fundamento para novas idéias. Em função disso, tais bens recebem a especial proteção, conforme determinação constitucional do art. 24, VII, e do art. 216, ambos da Constituição Federal.

Com isso, a preservação do bem não é de interesse só do seu proprietário ou do ente público que determina a sua conservação, ela é de todos.

Deste modo, o presente trabalho busca demonstrar como o imposto sobre a propriedade territorial urbana, de competência dos municípios pelo disposto no art. 156, I, da Constituição Federal, possui caráter extrafiscal e que tal característica pode ser utilizada pelas municipalidades como mecanismo de tutela da propriedade territorial urbana que é foi tombada por ser bem pertencente ao patrimônio histórico e arquitetônico daquela localidade.

Foram utilizadas consultas bibliográficas e jurisprudências para a elaboração de uma análise sobre a função do tombamento para a proteção do patrimônio histórico e arquitetônico

titular específico e real. Todavia, esse titular é facilmente determinado, a partir da verificação do direito em jogo.(...)

Aqui [nos direitos individuais homogêneos] os sujeitos são sempre mais de um e determinados.(...)Mas note-se: não se trata de litisconsórcio e sim de direito coletivo. Não é o caso de ajuntamento de várias pessoas, com direitos próprios e individuais no pólo da demanda, o que se dá no litisconsórcio ativo: quando se trata de direito individual homogêneo, a hipótese é de direito coletivo - o que permitirá, inclusive, o ingresso de ação judicial por parte dos legitimados no art. 82 da lei consumerista." In NUNES, Luis Antônio Rizzatto. Curso de Direito do Consumidor. São Paulo: Saraiva, 2008. p. 722/729.

6 Deste modo, eis a colocação de MILARÉ:

"A visão holística do meio ambiente leva-nos à consideração de seu caráter social, uma vez definido constitucionalmente como bem de uso comum do povo, caráter ao mesmo tempo histórico, porquanto o meio ambiente resulta das relações do ser humano com o mundo natural no decorrer do tempo..

Esta visão faz-nos incluir no conceito de meio ambiente, além dos ecossistemas naturais, as sucessivas criações do espírito humano que se traduzem nas suas múltiplas obras. Por isso, as modernas políticas ambientais consideram relevante ocupar-se do patrimônio cultural, expresso em realizações significativas que caracterizam, de maneira particular, os assentamentos humanos e as paisagens do seu entorno." In MILARÉ, Edis. Direito do Ambiente. São Paulo: Editora Revista dos Tribunais, 2000. p.183. Grifou-se. 
urbano, a função social da propriedade, a tributação incidente sobre os imóveis urbanos e, por fim, apresenta-se como o IPTU deve ser utilizado em favor da proteção aos bens tombados.

\title{
2.TOMBAMENTO ENQUANTO MECANISMO DE TUTELA DO PATRIMÔNIO HISTÓRICO E ARQUITETÔNICO URBANO
}

O homem, desde as eras mais primitivas, sempre marcou a natureza, refletindo o seu modo de viver. Com isso, ao longo do tempo, formou-se por todo o planeta um inestimável patrimônio histórico, que, desde o Iluminismo e a Revolução Francesa, tem sido objeto de tutela pelos Estados, pois a preservação da cultura de um povo é fator fundamental para a construção da sua nacionalidade e da sua identidade coletiva.

A conscientização da importância dos itens componentes de um patrimônio histórico trouxe para estes bens valor de mercado que pode ser facilmente constatado com a análise dos fluxos de capitais nos mercados de antiguidades e de obras de arte e do crescimento do tráfico destes bens.

Gandelman ${ }^{7}$ coloca que as primeiras políticas oficiais de conservação e preservação de monumentos históricos foram a francesa, por meio de um órgão estatal, e a inglesa, pela atuação da sociedade civil representada pelas associações de antiquários, e que em ambos os casos o tombamento foi o instrumento legal adotado para retirar da "esfera privada os bens, móveis ou imóveis, que se desejava proteger."

Neste sentido, vale destacar-se a lição de Fonseca8:

\begin{abstract}
A idéia de posse coletiva como parte de exercício da cidadania inspirou a utilização do termo patrimônio para designar o conjunto de bens de valor cultural que passaram a ser propriedade da nação, ou seja, do conjunto de todos os cidadãos. A construção do que chamamos de patrimônio histórico e artístico nacional partiu, portanto, de uma motivação prática - o novo estatuto da propriedade dos bens confiscados - e de uma motivação ideológica - a necessidade de ressemantizar esses bens.
\end{abstract}

Ao longo da história do Brasil independente houve a preocupação em formar-se uma identidade coletiva brasileira. Todavia, até a década de 1930 somente a cultura branca era valorizada quando observamos a preservação do patrimônio histórico-arquitetônico urbano.

7 GANDELMAN, Silvia Regina Dain. Acervos Culturais e Acesso ao Público: questões jurídicas. Dissertação (mestrado) - Centro de Pesquisa e Documentação de História Contemporânea do Brasil, Programa de Pós-graduação em história política e bens culturais. 2006. p.16/17.

8 FONSECA, Maria Cecília Londres. O patrimônio em processo. Rio de Janeiro: Editora UFRJ/Minc-IPHAN, 1997. p.58. Apud Ibidem. p.18. 
Apesar de em outras searas como a literatura e as artes plásticas já haver um movimento mais forte, principalmente após a lembrada Semana da Arte Moderna, que foi exemplo de valorização da cultura branca que gerou a cultura brasileira, após a antropofagia da cultura européia com o elemento mestiço. Posteriormente, outras manifestações culturais progressivamente passaram a ser aceitas, muitas vezes, com o rótulo de folclore.

Entretanto, a política de tombamentos, iniciada no Governo Vargas com o Serviço do Patrimônio Histórico Artístico Nacional (SPHAN), permaneceu voltada para a cultura branca e nem esta foi devidamente preservada naquele governo, tampouco nos posteriores. Logo, resta evidente que ainda há muito que ser preservado pela via do tombamento, principalmente, quando se observa os patrimônios deixados por negros, índios, orientais e todos os tipos de mestiços que formaram o povo brasileiro. ${ }^{9}$

Esta política de tombamentos foi fruto de uma política maior de proteção ao patrimônio histórico e de fomento da cultura que também seguiu as mesmas linhas de valorização da cultura branca que tem status constitucional desde a Constituição Brasileira de 1934, pois a Constituição do Império, de 1891, até protegia direitos autorais e inventos, mas com o objetivo de tutelar amplamente o direito de propriedade.

Assim, desde o princípio da política de preservação da memória brasileira, o tombamento é instrumento relevante, pois foi um dos mais utilizados, tendo em vista que por muito tempo importou a conservação do conjunto de bens culturais e materiais destacados pelo foco da cultura branca.

Todavia, não é porque o tombamento foi subutilizado durante este período, que ele deve ser descartado do daqui para frente. Ele é sempre foi um instrumento que se distinguiu pela sua eficiência em tutelar bens historicamente relevantes e, portanto, cabe o contínuo aprimoramento da sua aplicação para a construção de uma política mais abrangente de tutela do patrimônio histórico.

Como já destacado, o presente estudo tem como foco os bens imóveis urbanos, pois sobre eles haverá a incidência do Imposto sobre a Propriedade Territorial Urbana, no entanto a busca pela ampliação da preservação do patrimônio cultural brasileiro é de suma importância para a valorização não só de uma elite, mas também de minorias e também para fortalecer práticas de educação com mais qualidade e cidadania.

9 Assim, permanece atual a observação de Francisco Weffort que, em 2000, destacou que as inscrições no Livro do Tombo brasileiro refletem uma nação desde a sua origem branca, luso-brasileira e católica, ou seja, distanciam-se completamente da nossa realidade plural. In GANDELMAN, Silvia Regina Dain. Op. Cit. p.20. 
Historicamente, o tombamento foi o principal instrumento por permitir uma proteção ao bem, mesmo mantendo-o no patrimônio do particular, ou seja, trata-se de uma intervenção do Estado na propriedade privada que importa somente em uma restrição parcial da propriedade.

Apesar de existirem posições divergentes ${ }^{10}$, tem-se, principalmente pela jurisprudência $^{11}$, que o tombamento resulta de um ato administrativo discricionário e complexo que impõe uma limitação administrativa à propriedade após o curso de um processo administrativo.

Assim sendo, após o procedimento administrativo do tombamento, o bem passa a ser considerado bem de interesse público, mas não passa a compor o patrimônio público e o proprietário, em regra, não fará jus a indenização. Se, contudo, houver prova no caso concreto de que o tombamento importou em prejuízo para o proprietário ou para um terceiro, um locatário, por exemplo, deverá ocorrer a indenização e se uma restrição parcial ao direito de propriedade não for suficiente, a Administração Pública deverá proceder à desapropriação do imóvel, pagando ao proprietário uma indenização prévia, justa e em dinheiro, conforme a previsão constitucional do art. $5^{\circ}$, inciso XXIV, da Constituição Federal.

Vale destacar, ainda, que o procedimento administrativo do tombamento pode ter por objeto bens móveis ou imóveis, públicos ou privados; pode implicar em um tombamento provisório ou definitivo, individual ou geral; e pode seguir o procedimento de ofício, voluntário ou compulsório, como esquematicamente mostrado no fluxograma abaixo ${ }^{12}$.

10 Celso Antônio Bandeira de Mello, Ruy Cirne Lima e Adilson de Abreu Dallari, segundo Maria Sylvia Zanella Di Pietro, defendem que o tombamento é modalidade de servidão administrativa e ela própria define o tombamento como instituto autônomo da servidão administrativa e da limitação administrativa ao lado de José dos Santos Carvalho Filho. (PIETRO, Maria Sylvia Zanella di. Direito Administrativo. São Paulo: Editora Atlas, 2004. $17^{\mathrm{a}}$ Edição. p.141/142 e CARVALHO FILHO, José dos Santos. Op. Cit. p.682/683)

11 Neste sentido, Themistocles Cavalcanti e José Cretella Júnior e julgados recentes dos Tribunais: STJ/2 ${ }^{\mathrm{a}}$ Turma - RESP 401264, Relatora Ministra Eliana Calmon, DJ 30/09/02; TRF-1/2 ${ }^{\mathrm{a}}$ Turma - AC 9401075530, Relator JC Carlos Fernando Mathias, DJ 21/08/97; TRF-2/6 ${ }^{\mathrm{a}}$ Turma Especializada - AC 314988, Relator Des. Fed. Frederico Gueiros, DJU 14/07/09; TRF-2/7 ${ }^{\mathrm{a}}$ Turma Especializada - AC 425549, Relatora Des. Fed. Salete Maccaloz, DJU 24/04/09; TRF-2/6a Turma Especializada - AC 107446, Relator Des. Fed. Leopoldo Muylaert, DJU 05/12/08; TRF-2/7 ${ }^{a}$ Turma Especializada - AC 317817, Relator Des. Fed. Reis Friede, DJU 23/05/07. 12 PIETRO, Maria Sylvia Zanella di. Op. Cit. p.133/135. 

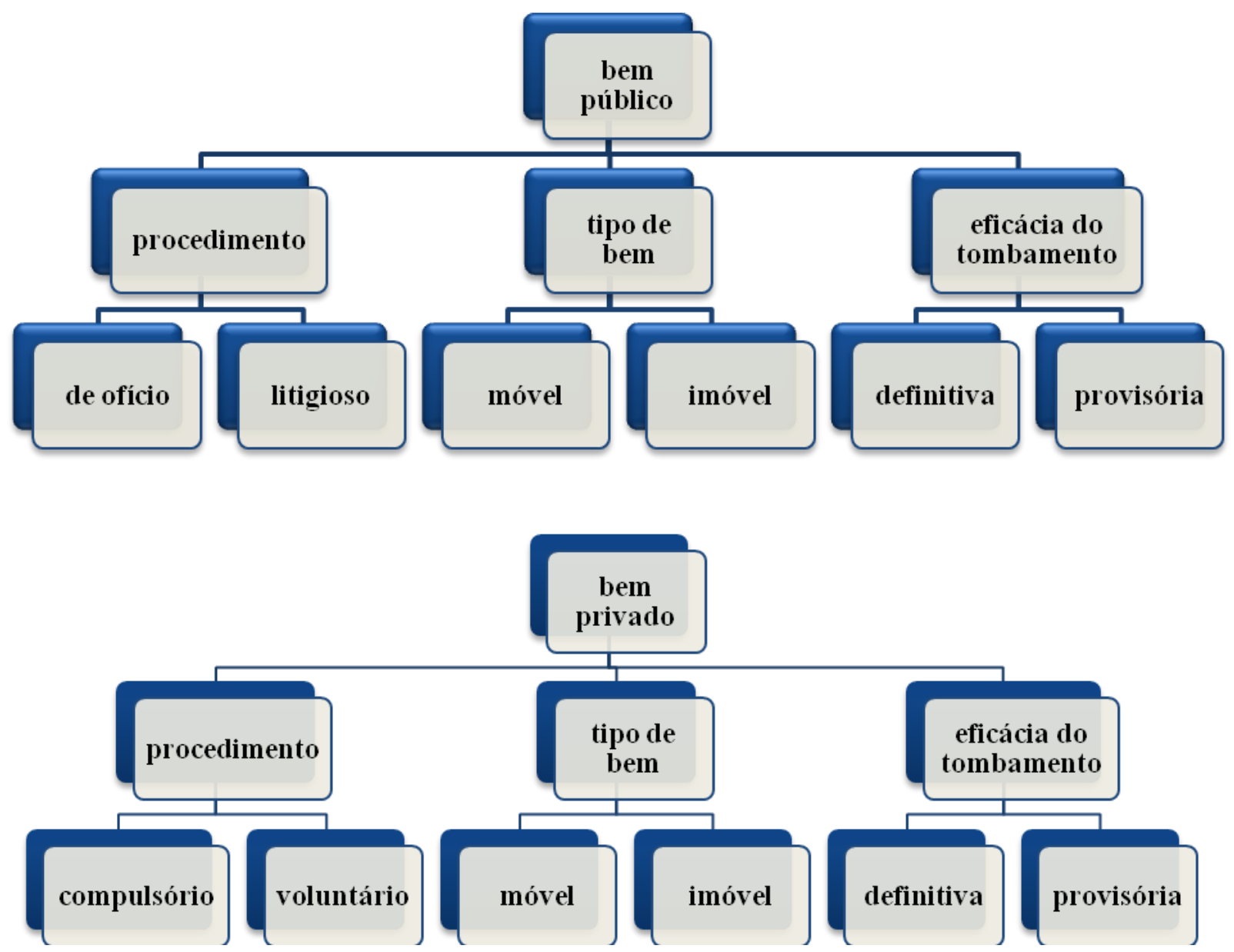

Apesar de ser possível o tombamento de bens público e de bens privados, importante realçar que o foco do presente trabalho lança-se sobre a propriedade urbana imóvel privado, posto que não deve haver tributação sobre os imóveis públicos tombados em função do princípio da imunidade recíproca.

O tombamento não é um ato administrativo, mas um processo administrativo, portanto sujeito ao devido processo legal, a ampla defesa e ao contraditório, valendo destaque a possibilidade de recurso hierárquico impróprio ao Presidente da República fixado pelo Decreto-lei no $3866 / 41$.

Crítica, entretanto, merece o rito fixado pelo Decreto-lei $n^{\circ} 25 / 37$ por não prever a notificação dos proprietários do imóveis vizinhos, o que deveria, ao nosso ver, ocorrer em homenagem à ampla defesa, posto que o tombamento gera obrigações de fazer e de não fazer para o proprietário do bem e, também, restringe o direito de construir dos terrenos vizinhos, conforme o art. 18 do referido Decreto-lei 25/37.

O proprietário tem o dever de não destruir o bem tombado e, ainda, o dever de conservá-lo dentro das suas características culturais que tornam o bem peculiar e ensejaram o tombamento, ou seja, a manutenção de um bem tombado é mais complexa e, normalmente, 
mais onerosa do que aquela necessária aos demais prédios. Consequentemente surge um custo muitas vezes alto demais para o proprietário. Se isto ocorrer, ele deve notificar a Administração Pública para que ela as providencie, valendo destacar que o Instituto do Patrimônio Histórico e Artístico Nacional (IPHAN) é o órgão responsável pela preservação do patrimônio histórico e artístico no âmbito federal e existem órgãos semelhantes no nível estadual e no municipal.

No entanto, ao optar por tombar o bem e não por desapropriá-lo, a Administração Pública demonstra que não quer inflar a máquina pública desnecessariamente, posto que é possível manter esse ônus da preservação do bem nas mãos da iniciativa privada, cabendo ao ente público a fiscalização.

Com isso, o poder público somente deve assumir o custo das reformas necessárias em bens tombados em último caso e, antes disso, é importante viabilizar-se o uso econômico do bem tombado e o acesso do proprietário ao crédito como formas de mantê-lo capaz de arcar com estas obrigações de modo a manter a finalidade do tombamento e evitando-se desapropriações desnecessárias por serem medidas mais gravosas.

\section{A FUNÇÃO SOCIAL DA PROPRIEDADE}

A propriedade é reconhecida pela Constituição da República Federativa do Brasil como um Direito Fundamental no seu art. $5^{\circ}$, XXII. Todavia, isto não o torna um direito absoluto, pois o próprio texto constitucional, no inciso XXIII, do mesmo art. $5^{\circ}$, determina que a propriedade somente seja lícita se exercida conforme a sua função social, sob pena de haver uma intervenção estatal sobre essa propriedade.

Carvalho Filho destaca que a função social da propriedade “autoriza não só a determinação de obrigações de fazer, como de deixar de fazer, sempre para impedir o uso egoístico e anti-social da propriedade. Por isso, o direito de propriedade é relativo e condicionado". ${ }^{13}$

Na mesma linha, segue a importante lição de Cretella Júnior ${ }^{14}$ :

Ao passo que o direito civil de propriedade confere ao titular cem por cento, vamos dizer, do jus utendi, fruendi et abutendi, o direito público da propriedade, que

13 CARVALHO FILHO, José dos Santos. Op. Cit.. p.658.

14 CRETELla JÚNIOR, José. Regime Jurídico do Tombamento. Revista de Direito Administrativo. n. 112. p.51. 
considera o bem dentro de um conjunto maior, vai reduzindo o quantum daquela fruição, porque observa a totalidade dos direitos de propriedade bem como a necessidade pública, a utilidade pública e o interesse social.

Mas quando a propriedade territorial urbana cumpre a sua função social, posto que a função social é um conceito jurídico aberto, ou seja, há uma incerteza quanto ao seu conteúdo a ser sanada pelo restante do ordenamento jurídico e pela atividade hermenêutica ?

A resposta desta pergunta está no art. $182, \S 2^{\circ}$, da CRFB, que diz que os parâmetros serão os fixados no plano diretor de cada cidade. Esta foi uma acertada decisão do constituinte $^{15}$. Afinal, apenas o Município é capaz de legislar sobre o que é exercer a função social da propriedade observando as peculiaridades locais, ainda que devendo sempre observar as normas gerais fixadas pela União no Estatuto da Cidade (lei 10.257/01).

Quando o proprietário não segue a função social conforme definida pelo Plano Diretor, o Estatuto da Cidade - ao regulamentar o art. 182 e o art. 183, ambos da Constituição Federal - prevê uma série de medidas, definidas no seu art. $5^{\circ}$, a serem tomadas pelo município como forma de progressivamente promover de forma compulsória o adequado uso do bem.

Em um primeiro momento a municipalidade pode determinar o parcelamento, a edificação ou a utilização compulsórios do solo urbano não edificado, subutilizado ou não utilizado, devendo fixar as condições e os prazos para implantação da referida obrigação. Caso esta medida não se apresente como eficaz pode ser aplicado ao imóvel o IPTU progressivo no tempo por até cinco anos e, em último grau, pode inclusive ocorrer a desapropriação com pagamento mediante títulos da dívida pública federal de emissão do Senado Federal, que serão resgatados no prazo de até dez anos, em prestações anuais, iguais e sucessivas, assegurados ao proprietário o valor real da indenização e os juros legais de seis por cento ao ano.

Desse modo, percebe-se que a função social da propriedade é o fundamento constitucional das formas de intervenção do Estado sobre a propriedade, inclusive do tombamento. Há, entretanto, controvérsia, sobre a existência de um segundo fundamento com base na supremacia do interesse público, pois Carvalho Filho a inclui ${ }^{16} \mathrm{e}$, em sentido oposto, o

15 Apesar de Liana Portilho Mattos destacar que a fórmula da função social urbana ter sido colocada de forma mais aberta que a rural pelo constituinte decorreu da crença dos setores mais conservadores de que o princípio sendo decorrente dos planos diretores nunca se concretizaria, afinal, nunca antes na história brasileira houve estes planos produziram os efeitos desejados. (In A efetividade da função social da propriedade urbana à luz do Estatuto da Cidade. Rio de Janeiro: Temas \& Idéias Editora, 2003. p.45. nota. 41.

16 CARVALHO FILHO, José dos Santos. op. cit. p.661. 
trabalho organizado por Sarmento ${ }^{17}$ tece duras críticas a este último princípio. Contudo, a função social da propriedade, exclusivamente analisada, já se apresenta mais do que suficiente para fundamentar as ações de tombamento.

Deve-se destacar que a função social da propriedade permite que o Estado deixe de ser puramente liberal e permite que sejam fixadas normas mínimas sobre como a propriedade deve ser exercida atendendo não somente aos interesses do proprietário, mas também da coletividade que a tutela e respeita, impedindo, portanto, o abuso no exercício do direito de propriedade. Assim, vale lembrar a expressão usada no art. 14.2, da Constituição Alemã: a propriedade obriga. Este enunciado demonstra a ampla mudança que a visão individualista sobre a propriedade sofreu ao longo da história.

Com isso, a existência da função social da propriedade urbana como cláusula aberta expõe um grande espaço que o Poder Constituinte Originário deixou para a deliberação democrática do legislador. Afinal, assim, o conteúdo mínimo deste princípio pode com mais facilidade ser atualizado de acordo com os preceitos constitucionais e com os interesses prevalecentes em cada período histórico, sem a necessidade de uma Emenda Constitucional.

Vários valores constitucionais estão intimamente ligados à função social da propriedade. A dignidade da pessoa humana e o direito à moradia se destacam neste contexto por auxiliarem o intérprete a extrair do princípio o seu melhor contorno.

Assim, a propriedade urbana deve ser exercida de modo a permitir que o cidadão tenha uma moradia digna e/ou que ela possa ser usada com insumo na produção de outras riquezas, como quando há o exercício da função social da empresa.

Mendes et alii $^{18}$ concluem sobre o tema da seguinte forma:

Não tendo a Constituição de 1988 estabelecido nenhuma hierarquia entre os valores consubstanciados no direito de propriedade e na sua função social, resta ao intérprete/ aplicador resolver seus eventuais "conflitos" à luz do caso concreto, mediante judiciosa ponderação, optando, afinal, por aquele cuja prevalência, nas circunstâncias, conduzir a uma decisão correta e justa e, assim, realizar a justiça em sentido material como referente fundamental da idéia de direito.

Por fim, cabe dizer que a determinação de que o plano diretor é obrigatório para os municípios com mais de vinte mil habitantes, contida no art. 182, da Constituição Federal é um dispositivo que permite que onde efetivamente há uma concentração de propriedade urbana exista o plano diretor como parâmetro para a função social da propriedade e para as

17 SARMENTO, Daniel Antonio de Moraes (Org.). Interesses públicos versus interesses privados: descontruindo o princípio da supremacia do interesse público. Rio de Janeiro: Lumen Juris, 2005.

18 MENDES, Gilmar Ferreira et alii. Curso de Direito Constitucional. São Paulo: Saraiva, 2008. p.1357. 
demais políticas urbanísticas. Ademais, considerando o ritmo de urbanização ${ }^{19}$ da população brasileira, é válido falar que a tendência é que as populações aglomerem-se em pólos urbanos, que certamente com o tempo vão atingir a marca dos vinte mil habitantes. Daí, pode-se inferir, que os planos diretores municipais representam instrumento importante para a efetividade do Estatuto das Cidades e da função social da propriedade urbana e, além disso, servem para auxiliar as Administrações Municipais a conter a indesejável urbanização descontrolada que ocorre atualmente no Brasil.

\section{TRIBUTAÇÃO SOBRE OS IMÓVEIS URBANOS}

A receita municipal decorrente de tributos é fixada constitucionalmente de modo a permitir que os Municípios tenham autonomia financeira para exercer as suas competências. Afinal, não é possível falar-se em autonomia dos entes federados sem tratar do tema das receitas. $^{20}$

A tabela abaixo relaciona as receitas municipais decorrentes de tributos.

\begin{tabular}{|l|l|}
\hline \multicolumn{2}{|c|}{ Receitas Municipais Tributárias } \\
\hline \multirow{2}{*}{ Impostos Municipais Originários $^{21}$} & $\underline{\text { IPTU }}$ \\
\cline { 2 - 2 } & ISS \\
\cline { 2 - 2 } & ITBI \\
\hline $\begin{array}{l}\text { Contribuição Social cobrada dos servidores municipais para o custeio do seu regime próprio de } \\
\text { previdência social }\end{array}$ & Contribuição de iluminação pública \\
\hline Taxas
\end{tabular}

19 Cf. SANTOS, Milton. A urbanização brasileira. 5a ed. São Paulo: Editora da Universidade de São Paulo, 2008.

20 Todavia, cumpre destacar que, na prática, os municípios não se revelaram hábeis para executar os seus impostos originários e para fomentar os seus fatos geradores. Neste sentido, segue a valiosa lição de Ives Gandra Martins:

"O Brasil é o único país do mundo civilizado a outorgar competência impositiva aos municípios, em nível constitucional. Outros países outorgaram-na, por legislação ordinária, mas tal delegação do poder central ou dos entes federados é excepcional. Vivem os municípios, mesmo nas Federações, da transferência de receita tributária.

O que mais releva acentuar, todavia, é que a transferência de receitas é mais eficaz que a competência impositiva própria. Os pequenos municípios ou de pequena densidade econômica não a exercem com resultados, razão pela qual a transferência de rendas tributárias, sobre desonerá-los de uma máquina arrecadadora que retira recursos do poder público, permite maiores disponibilidades para a sociedade.

Por esta razão, os demais países preferiram ofertar receita e não competência, receitas essas transferíveis, quase que de imediato, quando da recepção dos tributos pelo poder central ou pelos entes federativos." (In O Sistema Tributário na Constituição. São Paulo: Saraiva, 2008. p. 680/681.)

21 Rol de impostos taxativo, pois as competências extraordinária e a residual pertence à União Federal, conforme o art. 154, incisos I e II da CF. 


\begin{tabular}{|c|c|}
\hline \multicolumn{2}{|l|}{ Contribuições de melhoria } \\
\hline \multirow{2}{*}{$\begin{array}{l}\text { Participação em impostos originalmente } \\
\text { estaduais }\end{array}$} & $25 \%$ do ICMS n.f. do art. 158, par. único, CF \\
\hline & $50 \%$ do IPVA dos veículos licenciados em seu território. \\
\hline \multirow{3}{*}{$\begin{array}{l}\text { Participação em impostos originalmente } \\
\text { federais }\end{array}$} & $\begin{array}{l}\text { IR retido na fonte dos seus rendimentos e dos de suas } \\
\text { autarquias e fundações }\end{array}$ \\
\hline & $50 \%$ do ITR dos imóveis em seu território. \\
\hline & $0,7 \%$ do IOF - Ouro \\
\hline $\begin{array}{l}\text { Participação em contribuição de } \\
\text { intervenção no domínio econômico }\end{array}$ & 7,25\% da CIDE Combustíveis \\
\hline
\end{tabular}

Costata-se que existem os impostos originariamente municipais e um grande número de parcelas de participação em arrecadação alheia. Verifica-se, então, que o IPTU é somente uma das parcelas, mesmo sendo um imposto municipal originário de grande expressão.

Existe a previsão constitucional do IPTU no art. 156, I, entretanto, é a lei municipal que o instituirá.

Kiyoshi Harada ${ }^{22}$ destaca que "o IPTU é um imposto real que grava a disponibilidade econômica do imóvel”, por isso que além da propriedade, o domínio útil e a posse, que possua qualquer conteúdo econômico, mesmo que sem qualquer título formal ${ }^{23}$, no dia $1^{\circ}$ de janeiro de cada ano também representam fatos geradores deste imposto. A disponibilidade econômica é considerada também como o animus domini,segundo o STJ no RESP 325.489 da lavra da Ministra Eliana Calmon.

Quanto ao conceito de imóvel, posto que o imposto é sobre a propriedade predial e territorial urbana, este engloba os imóveis por natureza e os por acessão física, sendo que a ampliação da área construída importa em aumento do imposto devido, por representar um aumento de imóvel por acessão física.

A data de $1^{\circ}$ de janeiro de cada ano é usada como referência para a municipalidade lançar de ofício o tributo com base em seu cadastro de bens imóveis urbanos.

Afinal, o IPTU somente recai sobre a propriedade urbana e o art. $32, \S 1^{\circ}$, do Código Tributário Nacional ${ }^{24}$ diz que havendo pelo menos duas das melhorias deste rol, a propriedade será considerada urbana.

22 HARADA, Kiyoshi. Sistema Tributário na Constituição Federal de 1988. Curitiba: Juruá Editora, 2007. p.115.

23 Desse modo, não é sujeito passivo do IPTU o locatário, pois a posse com conteúdo econômico continua pertencendo ao locador. É esta também a situação do comandatário.

24 Art. 32. O imposto, de competência dos Municípios, sobre a propriedade predial e territorial urbana tem como fato gerador a propriedade, o domínio útil ou a posse de bem imóvel por natureza ou por acessão física, como definido na lei civil, localizado na zona urbana do Município. 
Percebe-se, então, que, para fins tributários, não é a finalidade dada ao território. Esta foi uma forma de fomentar as municipalidades a expandir estes serviços para todo o território municipal para que houvesse um crescimento no número de contribuintes do IPTU. Afinal, estes serviços estão ligados com a qualidade de vida mínima que o Estado deve oferecer a qualquer cidadão, urbano ou rural, para que este tenha uma vida digna.

A referida norma vai de encontro com a já mencionada urbanização crescente da população brasileira. Cada vez mais brasileiros vivem em cidades e possuem hábitos urbanos, mesmo quando trabalham em atividades diretamente ligadas ao campo ${ }^{25}$.

Vale salientar a lição de Harada ${ }^{26}$ :

Adotar o critério da destinação do imóvel para definir o que é rural seria
impossibilitar ao Município a missão de planejar e executar a política de
desenvolvimento urbano, por meio do plano diretor da cidade. Esclareça-se que o
STF proclamou a inconstitucionalidade do art. $6^{\circ}$ da Lei Federal 5.868 , de
12.12 .1972 que considerava como imóvel rural, independentemente de sua
localização, aquele destinado à exploração agrícola, pecuária, extrativa vegetal ou
agroindustrial (RE 93.850/MG -T. Pleno - Rel. Min. Moreira Alves, JSTF, Lex
46/91).

O valor venal á a base de cálculo do IPTU e deveria refletir o valor de mercado à vista, podendo oscilar no percentual de $10 \%$. Ele é calculado pela seguinte fórmula:

Valor venal $=[($ valor referencial fixado na planta de valores $) \mathrm{x}$ (indicador da posição) $\mathrm{x}$ (indicador da idade do imóvel) x (área do imóvel)]

O Pleno do STF, ao julgar o RE 92.355/SP, disse que a alteração em qualquer destas parcelas somente pode ser realizada por lei, ou seja, que era inconstitucional o decreto que visava majorar parcela. Com isso, o decreto somente pode realizar a atualização monetária destes valores.

Ainda quanto à base de calculo do IPTU, Alexandre" diz que "com o advento da EC 41/2003, o IPTU ficou sujeito à noventena (anterioridade nonagesimal). Entretanto, por força do art. $150, \S 1^{\circ}$, da $\mathrm{CF} / 1988$, as alterações da base de cálculo do tributo não estão sujeitas a este princípio."

$\S 1^{\circ}$ Para os efeitos deste imposto, entende-se como zona urbana a definida em lei municipal; observado o requisito mínimo da existência de melhoramentos indicados em pelo menos 2 (dois) dos incisos seguintes, construídos ou mantidos pelo Poder Público:

I - meio-fio ou calçamento, com canalização de águas pluviais;

II - abastecimento de água;

III - sistema de esgotos sanitários;

IV - rede de iluminação pública, com ou sem posteamento para distribuição domiciliar;

V - escola primária ou posto de saúde a uma distância máxima de 3 (três) quilômetros do imóvel considerado.

(BRASIL. Lei no 5172/66. Disponível em 31/10/09 em http://www.planalto.gov.br/ccivil_03/LEIS/L5172.htm.

Grifo nosso.)

25 Cf. SANTOS, Milton. Op. Cit.

26 HARADA, Kiyoshi. Op. Cit. p.116/117.

27 ALEXANDRE, Ricardo. Direito Tributário Esquematizado. São Paulo: Método, 2009. p.606. 
A alíquota do IPTU está sujeita a dois tipos de progressividade: fiscal e a extrafiscal ${ }^{28}$.

Por progressividade fiscal entende-se aquela que visa meramente o aumento da arrecadação, conforme o art. 156, $\$ 1^{\circ}$, inciso I, da Constituição Federal. Sendo que esta modalidade somente foi instituída com a Emenda Constitucional n ${ }^{\circ} 29 / 00^{29}$.

Frise-se quanto à progressividade a observação de Alexandre $^{30}$ :

\begin{abstract}
Ressalte-se não ser correta a afirmação genérica no sentido de que, a partir da EC 29/2000, os impostos reais passaram a poder ser progressivos. A citada emenda criou uma exceção a uma regra e, conforme é cediço em hermenêutica, as exceções devem ser interpretadas restritivamente. Por conseguinte, é lídimo afirmar que somente podem ser progressivos os impostos pessoais e os tributos em que a própria Constituição Federal autorize a adoção da sistemática. Ratificando este entendimento, registra-se que também foi necessária a edição de uma Emenda Constitucional para autorizar a progressividade do ITR (EC 42/2003, que incluiu o inciso I no art.153, $\S 4^{\circ}$, da $\mathrm{CF} / 88$ )
\end{abstract}

Antes da EC n ${ }^{\circ}$ 29/00, havia somente a progressividade extrafiscal prevista no art. 182, $\S 4^{\circ}$, inciso II, da Constituição Federal ${ }^{31}$. A extrafiscalidade é o uso do tributo com finalidade além da arrecadatória, no caso, a promoção do adequado uso do solo urbano, conforme a sua função social descrita no plano diretor, sendo a arrecadação apenas um efeito colateral da medida.

Além de permitir a progressividade fiscal, a EC nº 29/00 também instituiu no art. 156, $\S 1^{\circ}$, inciso II, da Constituição Federal a diferenciação de alíquotas com base na localização e no uso dado ao imóvel, sendo esta medida de claro caráter extrafiscal e que não pode ser diretamente associada à idéia de progressividade como nos casos anteriores. Desse modo, o uso residencial pode ser estimulado, prestigiando o direito à moradia, e imóveis localizados em áreas de risco como no caso das proximidades de favelas cariocas podem sofrer uma carga tributária menor quando comparados com os demais.

Considera-se plausível, ao contrário da posição exposta por Harada ${ }^{32}$, que exista esta diferenciação em função do local do imóvel e do seu uso, pois esta norma também tem que

28 As finalidades do tributo são assim explicadas por Alexandre:

"O tributo possui finalidade fiscal quando visa precipuamente arrecadar, carrear recursos para os cofres públicos. (...) O tributo possui finalidade extrafiscal quando objetiva fundamentalmente intervir em uma situação social ou econômica. (...) O tributo possui finalidade parafiscal quando a lei tributária nomeia sujeito ativo diverso da pessoa que a expediu, atribuindo-lhe a disponibilidade dos recursos arrecadados para o implemento dos seus objetivos.". Op. cit. p. 86.

29 "IPTU. Não se admite a progressividade fiscal decorrente da capacidade econômica do contribuinte, dada a natureza real do imposto. A progressividade da alíquota do IPTU, com base no valor venal do imóvel, só é admissível para o fim extrafiscal de assegurar o cumprimento da função social da propriedade urbana (art. 156, I, $\S 1^{\circ}$ e art. 182, $\S 4^{\circ}$, II, CF)." (AI 468.801-AgR, Rel. Min. Eros Grau, julgamento em 21-9-04, DJ de 15-10-04) 30 ALEXANDRE, Ricardo. Op. cit. p.602.

31 "É inconstitucional a lei municipal que tenha estabelecido, antes da emenda constitucional 29/2000, alíquotas progressivas para o IPTU, salvo se destinada a assegurar o cumprimento da função social da propriedade urbana." (Súmula 668 do Supremo Tribunal Federal)

32 HARADA, Kiyoshi. Op. Cit. p.119. 
submeter-se a todo o ordenamento jurídico, respeitando, portanto, a função social da propriedade, o direito a moradia e promovendo a redução das desigualdades sociais. Desse modo, se diferenciação de alíquotas em função do local e do uso do imóvel for implantada de modo a elitizar determinadas regiões, praticamente expulsando as camadas menos favorecidas, restará nítida a sua inconstitucionalidade por representar um confisco (art. 150, IV, CF) e por não observar aqueles valores constitucionais acima referidos.

\section{IPTU E A SUA VOCAÇÃO PARA EFETIVAR A FUNÇÃO SOCIAL DA PROPRIEDADE}

No quadro destacado na seção anterior há a demonstração de que o IPTU constitui uma das principais fontes de arrecadação dos municípios principalmente em função do seu forte caráter fiscal. Por outro lado, é pacífico que há um caráter extrafiscal no IPTU que foi reforçado após a EC nº 29/00.

É importante, no entanto, o destaque para o fato de que a arrecadação do IPTU decorrente da propriedade de imóveis tombados é, em regra, uma pequena porcentagem da arrecadação municipal, posto que normalmente a maioria dos imóveis urbanos não se encontra nesta especial condição.

Como já exposto, há uma necessidade de o Poder Público buscar a proteção do patrimônio histórico e cultural, inclusive no seu viés arquitetônico, mas também oferecer a tutela do direto à moradia $\mathrm{e}$ o fortalecimento da função social da propriedade. Consequentemente, as políticas públicas devem ser resultado da formulação de um plano de ação que coordene todas estas atividades de modo que, por exemplo, uma ação em prol da moradia, não represente uma irreparável perda ao patrimônio histórico urbano.

Com isso, mecanismos de tributação com caráter extrafiscal para atingir esse tipo de meta apresentam-se como ferramenta cujo uso está em franco crescimento. Podemos citar os casos dos incentivos fiscais em favor da cultura fixados pelo artigo 18 da lei 8313/91, também chamada de lei Rouanet, e a redução das alíquotas de IPI para os itens da "linha branca" que possuem indicadores de baixa poluição.

Não há que se falar aqui no erro da "tributação cultural", tal qual se fala em “tributação ambiental". Tanto na tutela dos bens culturais, como na do meio-ambiente, o que 
existe é o uso extrafiscal da tributação já existente. Neste sentido, vale destacar a lição de Borges $^{33}$ :

\begin{abstract}
"O termo é equivocado, por dois motivos. O primeiro se encontra no fato de que tributação enseja um fazer do Estado, mais precisamente, na criação de tributos incidentes sobre o meio ambiente. Sendo assim, do ponto de vista técnico, isto é impossível, na medida em que considera o meio ambiente um bem privado, sujeito à incidência de tributos, contrariando o explicitado no art. 225 da CF, que prevê que o meio ambiente é bem de uso comum do povo. Já o segundo está pautado na realidade. $\mathrm{O}$ que ocorre são incentivos fiscais àqueles que regem suas atividades produtivas pautadas na preservação ambiental, ou uma majoração dos tributos já existentes com o intuito de reprimir práticas produtivas deletérias ao meio ambiente, como forma de efetivar o equilíbrio entre os agentes econômicos concorrentes.

Outro ponto de extrema relevância mencionado por Modé é a de que tal "tributação" não tem caráter sancionatório. Em suas palavras, ele afirma: "a tributação ambiental diferencia-se do caráter sancionatório por não se aplicar a atividades ilícitas. A tributação ambiental aplica-se tão somente à atividades lícitas, assim consideradas pelo legislador porque necessárias, em que pese o impacto do meio ambiente."

Ora, nenhuma atividade tributária em qualquer das esferas, sejam elas federal, estadual ou municipal, tem natureza sancionatória. Pela própria redação do art. $3^{\circ}$ do Código Tributário Nacional, onde há a clara menção que tributo não decorre de sanção de ato ilícito, depreende-se tal entendimento.
\end{abstract}

Desse modo, como o IPTU incide sobre toda a propriedade territorial urbana, sua regulamentação deve tentar direcionar o seu caráter extrafiscal. Valorizar a função social da propriedade que determina um uso dos bens com relevante valor histórico que implique na sua conservação é uma forma importante de aplicação da função social da propriedade, pois dá ao imóvel não somente uma destinação econômica razoável, mas vai além reforçando a cultura daquela coletividade.

Nesta linha, a municipalidade pode graduar as alíquotas do IPTU ${ }^{34}$, podendo, inclusive, chegar à alíquota zero ${ }^{35}$, de modo que o proprietário do bem imóvel tombado e preservado dentro das especificações fixadas pelo poder público não tenha que pagar o referido imposto.

33 BORGES, Marcos Aurélio dos Santos. Sistema Tributário Nacional e Política Nacional de MeioAmbiente - A Extrafiscalidade Pró-Ambiente. Monografia - FGV Direito Rio. 2009. p. 6/7.

34 “A fixação de alíquotas diferenciadas em razão da construção ou da destinação do imóvel é possível e encontra amparo legal; logo, a fixação de alíquota para imóveis edificados ou não-edificados, e para residenciais ou não residenciais não pode ser considerada ilegal." TJRJ - 12 ${ }^{\mathrm{a}}$ Câmara Cível. AC 16466/2002. Relator Desembargador Francisco de Assis Pessanha. j.18/03/03.

${ }^{35}$ Quanto à diferenciação entre imunidade, não incidência, isenção e alíquota zero: "Resumindo o que foi dito sobre as quatro formas até o presente, tem-se que na imunidade não nasce nem obrigação tributária, nem o crédito correspondente, por força de vedação absoluta da Carta Magna ao poder de tributar. Na não incidência não nasce obrigação tributária, nem o crédito respectivo, por força do não exercício da capacidade - ou na linguagem constitucional - da competência, a que tem direito o Poder Tributante. Na isenção nasce a obrigação tributária, mas não nasce o crédito tributário, em face de estímulo legal expresso. Na alíquota zero nascem a obrigação tributária e o crédito tributário, que ficam, todavia, reduzidos à expressão nenhuma." MARTINS, Ives Gandra da Silva. IPI: distinção entre imunidade, isenção, não incidência e alíquota zero in Direito Empresarial - Pareceres. Rio de Janeiro: Forense, 1986. p.298/317, apud FOLMANN, Melissa (coord.). Tributação e Direitos Fundamentais - Propostas de Efetividade. Curitiba: Juruá, 2007. p.317. 
Com isso, estes proprietários recebem do poder público um incentivo financeiro para a manutenção destes bens que, em regra, envolvem valores maiores que aqueles arcados para as benfeitorias úteis e necessárias de bens imóveis não tombados.

Há ainda legislações municipais que concedem isenção de IPTU para todos os imóveis tombados $^{36}$. Considera-se aqui que esta não é a melhor prática por não exigir a efetiva conservação do bem para que seja concedido o tratamento diferenciado.

Desse modo, considerando-se que a preservação de um bem tombado é em si exercício da função social da propriedade, pode-se entender que pode ocorrer a redução da carga tributária do IPTU em favor da preservação do patrimônio histórico e arquitetônico do mesmo modo como o Supremo Tribunal Federal aceita a redução do IPTU em prol do direito à moradia. Assim, justa é a colocação da súmula 539 do STF ao defender o direito fundamental à moradia e a função social da propriedade: “É constitucional a lei do município que reduz o imposto predial urbano sobre imóvel ocupado pela residência do proprietário, que não possua outro."

\section{CONCLUSÃO}

Após este breve estudo, pode-se concluir que o patrimônio arquitetônico urbano é parte do patrimônio histórico e cultural e este, por sua vez, deve ser protegido como registro da cultura brasileira e como parte do meio ambiente modificado pela ação do homem.

Cada imóvel é parte do patrimônio de alguém, seja o proprietário pessoa física ou jurídica, de direito público ou privado. A propriedade é um direito que é fundamental, mas que não é absoluto e o principal parâmetro que o relativiza é o exercício da função social da propriedade.

A proteção do patrimônio histórico e cultural é de competência de todos os entes federados e também dos cidadãos, que não podem vilipendiar o acervo existente sob pena de impedir o seu acesso pelas futuras gerações.

Com isso, foram criados mecanismos de proteção aos bens relevantes para a formação do patrimônio histórico e cultural. Um dos mais tradicionais e eficientes instrumentos para os

\footnotetext{
${ }^{36}$ Nesta linha, a título de exemplo: Lei de Campinas/SP no $11.111 / 2001$. Art. $4^{\text {o }}$, VIII e Lei do Rio de Janeiro/RJ nº 691/84. Art.61, I.
} 
bens imóveis é o tombamento por não retirar o bem do patrimônio do seu proprietário, mas por limitar o exercício do direito de propriedade de modo que sejam conservadas as características do imóvel.

Como no tombamento não há expropriação, em regra não ocorre o dever de indenizar, mas, ainda que seja demonstrado o dano, o custo para o ente que promove o tombamento tende a ser menor do que se fosse feita a desapropriação do bem.

Assim, o tombamento permite a proteção do imóvel, sem expropriar o bem e com um custo menor para o erário. Logo, conclui-se que o estímulo ao uso do tombamento nas políticas públicas sobre a cultura e o meio ambiente é algo salutar.

Porém, não basta o ato do tombamento. É necessária a efetiva conservação do bem.

Surge, então, a problemática de como obter recursos para tais encargos de manutenção se o uso do bem é bem mais restrito por ser tombado e as benfeitorias úteis e necessárias muito mais onerosas pelo mesmo motivo.

Haveria a possibilidade do próprio ente público fazer a reforma, todavia, não faz sentido tombar o bem e colocar como primeira opção o Estado realizando as reformas. Pois, se fosse para fazê-lo, melhor teria sido desapropriar o bem.

Desse modo, esta deve ser a última opção da Administração Pública.

Antes dela, é importante fomentar o uso do bem em atividades que não o deteriorem, mas que geram retorno econômico. Neste sentido, podemos destacar a iniciativa dos pólos gastronômicos do Rio de Janeiro que nas regiões cariocas da Lapa e da Praça XV têm permitido a reforma de sobrados tombados e o seu uso como restaurantes, revitalizando sobremaneira a economia destas áreas.

Outra opção, é a criação de linhas de crédito para os proprietários por bancos públicos como o BNDES e a Caixa Econômica Federal.

Por fim, eis a opção que apresentamos neste trabalho: o uso de redução nas alíquotas do IPTU incidentes sobre os bens tombados e devidamente conservados. Esta via parece muito importante por dois motivos.

Este tipo de uso extrafiscal do IPTU, pelo fato do número de bens tombados não ser muito alto nas nossas cidades, não gera grandes perdas arrecadatórias e permite que a municipalidade seja interessada a vistoriar regularmente os imóveis tombados, pois em um primeiro momento haverá o pedido de inclusão do bem tombado no programa de benefícios pelo seu proprietário e, posteriormente, a Administração municipal tem o empenho fiscalizatório quando isto pode representar um acréscimo da arrecadação. 
Ademais, há o interesse de o contribuinte receber o benefício e isto o estimula a preservar o bem, mesmo quando ele não possui a devida consciência da importância daquele imóvel para a história e a cultura do país.

Deste modo, conclui-se que o tombamento é uma ferramenta muito útil para a proteção do patrimônio histórico e arquitetônico e que o IPTU pode ser usado como meio de auxiliar este mecanismo na tutela destes bens em função do seu caráter extrafiscal aplicado ao estímulo da função social da propriedade.

\section{REFERÊNCIAS BIBLIOGRÁFICAS}

ALEXANDRE, Ricardo. Direito Tributário Esquematizado. São Paulo: Método, 2009.

BORGES, Marcos Aurélio dos Santos. Sistema Tributário Nacional e Política Nacional de Meio-zmbiente - A Extrafiscalidade Pró-ambiente. Monografia - FGV Direito Rio. 2009.

CARVAlHO FILHO, José dos Santos. Manual de Direito Administrativo. Rio de Janeiro: Lumen Juris, 2007.

CASTRO, Sônia Rabello de. O Estado na preservação de bens culturais. Rio de Janeiro: Renovar, 1991.

CRETELlA JÚNIOR, José. Regime Jurídico do Tombamento. Revista de Direito Administrativo. n. 112.

FOLMANN, Melissa (coord.). Tributação e Direitos Fundamentais - Propostas de Efetividade. Curitiba: Juruá, 2007.

GANDELman, Silvia Regina Dain. Acervos Culturais e Acesso ao Público: questões jurídicas. Dissertação (mestrado) - Centro de Pesquisa e Documentação de História Contemporânea do Brasil, Programa de pós-graduação em história política e bens culturais: 2006.

HARADA, Kiyoshi. Sistema Tributário na Constituição Federal de 1988. Curitiba: Juruá Editora, 2007.

MACHADO, Paulo Afonso Leme. Direito Ambiental Brasileiro. São Paulo: Malheiros Editores, 2005. 
MARTINS, Ives Gandra. O Sistema Tributário na Constituição. São Paulo: Saraiva, 2008.

MATTOS, Liana Portilho. A efetividade da função social da propriedade urbana à luz do Estatuto da Cidade. Rio de Janeiro: Temas \& Idéias Editora, 2003

MENDES, Gilmar Ferreira, COELHO, Inocêncio Mártires, e BRANCO, Paulo Gustavo Gonet. Curso de Direito Constitucional. São Paulo: Saraiva, 2008.

MILARÉ, Édis. Direito do Ambiente. São Paulo: Editora Revista dos Tribunais, 2000.

MOREIRA NETO, Diogo de Figueiredo. Curso de Direito Administrativo. Rio de Janeiro: Forense, 1989.

NUNES, Luis Antônio Rizzatto. Curso de Direito do Consumidor. São Paulo: Saraiva, 2008.

PIETRO, Maria Sylvia Zanella di. Direito Administrativo. São Paulo: Editora Atlas, 2004. $17^{\mathrm{a}}$ Edição.

SANTOS, Milton. A urbanização brasileira. $5^{\text {a }}$ ed. São Paulo: Editora da Universidade de São Paulo, 2008.

SARMENTO, Daniel Antônio de Moraes (Org.). Interesses públicos versus interesses privados: descontruindo o princípio da supremacia do interesse público. Rio de Janeiro: Lumen Juris, 2005.

TELLES, Antônio A. Queiroz. Tombamento e seu regime jurídico. São Paulo: Editora Revista dos Tribunais, 1992. 